\title{
The study of physical, anthropometric and physiological status for Saudi Arabian sitting volleyball players by playing positions
}

\section{"Dr/ Mohamed Salama Younis}

\section{Introduction \& Research Problem}

In the past 10 years, the Olympic games of the disabled set an example of quality and excitement in the elite level of disabled sports and its great progress. In a brief historical glimpse, the disabled sport witnessed huge changes regards its participation, organization and financing, however, the literatures that follow, evaluate and increase the cognitive structure of these developments are rare.

There is no doubt that the physically disabled practice of diverse athletic activities allows a positive relationship that helps the individual to fit in the society. No doubt that the relation between health and sport was not strong and associated as it is now. Sport is a means for a better healthy life, also health must be an aim preserved by the athletic when practicing sport and attempting to achieve high athletic levels. There has been a huge increase in the number of people suffering from physical disability, which in turn increased the participation of some forms of recreation or competitive sport. Legislation initiatives, technological progress and the change of social norms are the three main reasons behind this increase in participation. Considering this growth, the participation increased in these recreation and athletic opportunities. Surprisingly, there is a lack of the literatures dedicated to understand types and patterns of disability (10).

"Associate professor Faculty of Physical Education, Sadat City University, Egypt 
Helmy Ibrahim and Layla Farahat (1998) indicated that the disabled person is different in all or one of the physical, mental, psychological or social aspects to the limit that require special rehabilitation processes to achieve the maximum adaptation; his remained abilities and potentials allow. (96: 1)

The sitting volleyball activity (for the physically disabled) is one of the most spreading athletic activities in the practice sector of the physically disabled as it enjoys a team competitive and recreation nature. This game became dynamic and results in high excitement level specially when practicing the technical and tactical requirements of the game. Alsaied Abdel Maksoud (1997) indicated that the profile of each athletic activity has to be determined according to the activity requirements and the suitable training procedures. Of the important matters in training is to know which muscle and in which trainings, also which level of load. Body parts differ in concentration when developing the strength level in certain muscle groups, in other parts, this level is developed in all the muscle groups in general. (153:2)

The researcher noticed that the Saudi Arabia concern of this sector, and in the same time he noticed the lack of literatures in the field of disabled sport and specifically the sitting volleyball in Saudi Arabia; which encouraged the researcher to study the physical, anthropometric and physiological status of sitting volleyball players, which is considered of great importance to adjust and direct the form of this athletic practice in a way that suits the aim of this practice from the motor and functional aspects. Volleyball represents a special importance for the disabled in order to improve life quality, in addition to the competitive activity, and accordingly to open scientific horizons in order to put research methods for the scientific studies of the physically disabled to make 
use of the effect of athletic practice in this sector which became part of the societies, including the Saudi society.

\section{Research Aims:}

This research aims to recognize the following:

1- The physical characteristics of (sitting) volleyball disabled players in Saudi Arabia.

2- The anthropometric characteristics of (sitting) volleyball disabled players in Saudi Arabia.

3- The physiological characteristics of (sitting) volleyball disabled players in Saudi Arabia.

4- $\quad$ Studying the differences between play positions in the physical, physiological and anthropometric characteristics of (sitting) volleyball disabled players in Saudi Arabia.

\section{Research Questions:}

1- What are the physical changes of (sitting) volleyball disabled players in Saudi Arabia?

2- What are the physiological changes of (sitting) volleyball disabled players in Saudi Arabia?

3- What are the anthropometric changes of (sitting) volleyball disabled players in Saudi Arabia?

4- Are there any statistical significant differences between the anthropometric, physiological and physical variables between the play positions of (sitting) volleyball disabled players in Saudi Arabia?

\section{Research Method:}

The study included 15 participants physically disabled athletes, sitting volleyball players from Saudi Arabia (mean age 28.8 years; SD 3.1 years). This study employed a number of fitness tests: 9 meter-speed test, agility (shuttle run test 15 meter), side step test, horizontal block test, sit-ups test, medicine ball throwing test, cross movement , grip strength test, anthropometric measurement: a) width of elbow, wrist, arm spam, acromial -b) length of hand, elbow-wrist, shoulderelbow, sitting height $-\mathrm{c}$ ) 
circumferences of arm, forearm, wrist), block sitting and physiological measurement (Vital capacity ,FCV1). ANOVA and LSD were used to find differences between players positions in physical and physiological variables, as well as body measurement.

\section{Research Sample:}

The sample was chosen deliberately from Mecca Club for special needs of (sitting) volleyball disabled players who are registered in the Saudi Paralympics committee season
2012/2013. The research sample number was (15) players; chosen to participate in the Saudi Championship.

Research Sample

\section{Consistency:}

To make sure that the research sample individuals under the equinoctial curve, the researcher performed the consistency between the research sample individuals in the following variables (age, weight, height from sitting, training age); as shown in table (1).

Table (1)

Research sample consistency in some selected variables $(N=15)$

\begin{tabular}{|c|c|c|c|c|c|c|c|c|}
\hline \multirow[b]{2}{*}{ No. } & \multirow{2}{*}{$\begin{array}{l}\text { Play } \\
\text { position } \\
\text { Variables }\end{array}$} & \multirow[b]{2}{*}{$\begin{array}{c}\text { Measurement } \\
\text { unit }\end{array}$} & \multicolumn{2}{|c|}{ Position 2} & \multicolumn{2}{|c|}{ Position 3} & \multicolumn{2}{|c|}{ Position 4} \\
\hline & & & means & SD & means & SD & means & SD \\
\hline 1 & Age & year & 25.80 & 2.58 & 29.40 & 4.33 & 28.20 & 2.49 \\
\hline 2 & $\begin{array}{l}\text { Sitting } \\
\text { height }\end{array}$ & $\mathrm{cm}$. & 88.60 & 4.72 & 85.60 & 1.51 & 86.40 & 2.70 \\
\hline 3 & Weight & Kg. & 73.00 & 11.42 & 79.40 & 4.03 & 73.20 & 2.38 \\
\hline 4 & $\begin{array}{l}\text { Training } \\
\text { age }\end{array}$ & Year & 9.20 & 1.64 & 12.80 & 5.54 & 12.60 & 2.07 \\
\hline
\end{tabular}

Display of Results: 
Table (2)

Disparity analysis between the measurements of players' positions in the studied physical variables $(\mathrm{N}=15)$

\begin{tabular}{|c|c|c|c|c|c|c|c|c|c|c|c|c|}
\hline \multicolumn{3}{|c|}{$\begin{array}{c}\text { Play positions } \\
\text { Variables }\end{array}$} & \multicolumn{2}{|c|}{$\begin{array}{l}\text { measruing } \\
\text { unit }\end{array}$} & \multicolumn{2}{|c|}{ Position 2} & Position 3 & \multicolumn{2}{|c|}{ Position 4} & Sig. & \multicolumn{2}{|c|}{ D Value } \\
\hline \multirow{7}{*}{$\begin{array}{l}\frac{\mathscr{d}}{0} \\
\cdot \frac{\pi}{\pi} \\
> \\
\cdot \frac{0}{\infty} \\
\frac{\pi}{2}\end{array}$} & $\begin{array}{l}9 \\
\text { speed }\end{array}$ & $\mathrm{m}$. & \multicolumn{2}{|c|}{ Sec. } & \multicolumn{2}{|c|}{$3.91 \pm 0.43$} & $4.15 \pm 0.48$ & \multicolumn{2}{|c|}{ $\pm 8.53 .45$} & .072 & 3.311 & Insignificant \\
\hline & $\begin{array}{l}\text { Shuttle } \\
\text { runnin }\end{array}$ & & \multicolumn{2}{|c|}{ Sec. } & \multicolumn{2}{|c|}{$8.95 \pm 1.05$} & $8.73 \pm 1.14$ & \multicolumn{2}{|c|}{$8.51 \pm 0.75$} & .790 & .241 & Insignificant \\
\hline & Side $m$ & ove & \multicolumn{2}{|c|}{ Num. } & \multicolumn{2}{|c|}{$13.20 \pm 2.16$} & $14.80 \pm 2.77$ & \multicolumn{2}{|c|}{$14.8 \pm 1.64$} & .453 & .848 & Insignificant \\
\hline & $\begin{array}{l}\text { Horizo } \\
\text { block } \\
\text { sec. }\end{array}$ & $\begin{array}{r}\text { ntal } \\
20\end{array}$ & \multicolumn{2}{|c|}{ Num. } & \multicolumn{2}{|c|}{$12.60 \pm 1.67$} & $14.20 \pm 1.5$ & \multicolumn{2}{|c|}{$12.60 \pm 2.30$} & .323 & 1.243 & Insignificant \\
\hline & \multicolumn{2}{|c|}{$\begin{array}{l}\text { Moving as } \\
\text { (x) shape }\end{array}$} & \multicolumn{2}{|c|}{ Num. } & \multicolumn{2}{|c|}{$14 \pm 2.34$} & $\begin{array}{l}14.80 \\
\pm 1.78\end{array}$ & \multicolumn{2}{|c|}{$\begin{array}{ll}14.40 \quad \pm \\
0.89 & \end{array}$} & .781 & .253 & Insignificant \\
\hline & \multicolumn{2}{|c|}{$\begin{array}{l}12 \text { sec. } \\
\text { abdomen }\end{array}$} & \multicolumn{2}{|c|}{ Num. } & \multicolumn{2}{|c|}{$14 \pm 2.88$} & $13.80 \pm 2.77$ & \multicolumn{2}{|c|}{$13.20 \pm 1.78$} & .688 & .385 & Insignificant \\
\hline & \multicolumn{2}{|c|}{$\begin{array}{l}\text { Throwing } \\
\text { medical ball }\end{array}$} & \multicolumn{2}{|c|}{$\mathrm{cm}$. } & \multicolumn{2}{|c|}{$10.42 \pm 3.29$} & $11.07 \pm 1.52$ & & \pm 1.59 & .567 & .595 & Insignificant \\
\hline & & & & ight & & $2 \pm 7.15$ & $49.2 \pm 8.28$ & & $3 \pm 4.15$ & .242 & 1.603 & Insignificant \\
\hline Hal & $\mathrm{d}$ grip & & $\mathrm{L}$ & $\mathrm{ft}$ & $\begin{array}{l}48 \\
7.4\end{array}$ & $\begin{array}{ll}40 & \pm \\
3 & \end{array}$ & $46.4 \pm 7.02$ & & $5 \pm 3.04$ & .158 & 2.162 & Insignificant \\
\hline & $\begin{array}{l}\text { (D) } 1 \\
\text { tempe } \\
4.256 \\
\text { there } \\
\text { Disps }\end{array}$ & $\begin{array}{l}\mathrm{Tal} \\
\text { are }\end{array}$ & & $\begin{array}{c}\text { alue at } \\
\text { degre } \\
(2) \\
\text { statist } \\
\text { nalysis } \\
\text { the stu }\end{array}$ & & $\begin{array}{l}(7.2)= \\
\text { ws that } \\
\text { morale } \\
\text { ween th } \\
\text { d anthro }\end{array}$ & Table (3) & & $\begin{array}{l}\text { cant di } \\
\text { rement } \\
\text { he } \mathrm{s} \\
\text { les. } \\
\text { nts of } \\
\text { ciables }\end{array}$ & $\begin{array}{l}\text { fferen } \\
\text { amor } \\
\text { s of } p \\
\text { tudie }\end{array}$ & $\begin{array}{l}\mathrm{ces} a \\
\lg \\
\operatorname{lay} \mathrm{po} \\
\mathrm{d}\end{array}$ & $\begin{array}{r}\text { level } \\
\text { the } \\
\text { sitions } \\
\text { nysical }\end{array}$ \\
\hline & $\begin{array}{l}\text { thropom } \\
\text { easurem } \\
\text { lay posit }\end{array}$ & $\begin{array}{l}\text { etric } \\
\text { ents } \\
\text { ion }\end{array}$ & & $\begin{array}{r}\text { measuri } \\
\text { unit }\end{array}$ & & $\begin{array}{c}\text { Position } \\
2\end{array}$ & Position & & $\begin{array}{c}\text { Position } \\
4\end{array}$ & Sig. & & (D) value \\
\hline & $\begin{array}{l}\text { Elbow } \\
\text { width }\end{array}$ & Rig & & $\mathrm{cm}$. & & $7.1 \pm 0.74$ & $7.24 \pm 0$. & & $7 \pm 0.21$ & .747 & .299 & Insignificant \\
\hline 胥 & $\begin{array}{l}\text { Wrist } \\
\text { width }\end{array}$ & Rig & & $\mathrm{cm}$. & & $5.74 \pm 0.32$ & $5.80 \pm 0$ & & $\begin{array}{ll}5.76 & \pm \\
0.33 & \end{array}$ & .966 & .035 & Insignificant \\
\hline & acromior & widt & & $\mathrm{cm}$. & & $42.54 \pm 2.74$ & $43.20 \pm 2$. & & $42.88 \pm 1.62$ & .902 & .104 & Insignificant \\
\hline & Arms'v & idth & & $\mathrm{cm}$. & & $192.8 \pm 3.56$ & $189.20 \pm 3$ & & $197 \pm 5.85$ & .033 & 4.617 & significant \\
\hline
\end{tabular}


Table (3)

Disparity analysis between the measurements of players' positions in the studied anthropometric variables $(N=15)$

\begin{tabular}{|c|c|c|c|c|c|c|c|c|}
\hline \multicolumn{2}{|c|}{$\begin{array}{l}\text { Anthropometric } \\
\text { measurements } \\
\text { Play position }\end{array}$} & $\begin{array}{c}\text { measuring } \\
\text { unit }\end{array}$ & $\begin{array}{c}\text { Position } \\
2\end{array}$ & Position 3 & $\begin{array}{c}\text { Position } \\
4\end{array}$ & Sig. & \multicolumn{2}{|c|}{ (D) value } \\
\hline \multicolumn{2}{|c|}{ Sitting to block } & $\mathrm{cm}$. & $\begin{array}{ll}150.6 \quad \pm \\
4.39\end{array}$ & $155.6 \pm 1.14$ & $\begin{array}{l}149.2 \pm \\
1.30\end{array}$ & .007 & 7.614 & significant \\
\hline \multirow{4}{*}{ 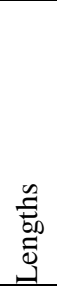 } & sitting height & $\mathrm{cm}$. & $\begin{array}{ll}88.6 & \pm \\
4.72 & \end{array}$ & $85.6 \pm 1.51$ & $\begin{array}{ll}86.4 & \pm \\
2.70 & \end{array}$ & .354 & 1.135 & Insignificant \\
\hline & Hand length & $\mathrm{cm}$. & $\begin{array}{ll}20.30 \quad \pm \\
1.78\end{array}$ & $21.4 \pm 0.89$ & $\begin{array}{ll}20.2 & \pm \\
0.74 & \end{array}$ & .239 & 1.615 & Insignificant \\
\hline & $\begin{array}{l}\text { Humerus } \\
\text { length }\end{array}$ & $\mathrm{cm}$. & $\begin{array}{l}33.30 \quad \pm \\
2.38\end{array}$ & $34.2 \pm 1.64$ & $\begin{array}{ll}33.6 & \pm \\
1.55 & \end{array}$ & .753 & .291 & Insignificant \\
\hline & $\begin{array}{l}\text { Forearm } \\
\text { length }\end{array}$ & $\mathrm{cm}$. & $\begin{array}{ll}29.3 & \pm \\
2.28 & \end{array}$ & $30.3 \pm 7.15$ & $\begin{array}{l}51.2 \quad \pm \\
7.15\end{array}$ & .637 & .468 & Insignificant \\
\hline \multirow{3}{*}{ 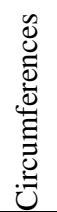 } & Arm & $\mathrm{cm}$. & $\begin{array}{l}30.7 \\
5.04\end{array}$ & $33.2 \pm 4.45$ & $\begin{array}{ll}32.2 & \pm \\
2.48 & \end{array}$ & .676 & .405 & Insignificant \\
\hline & Forearm & $\mathrm{cm}$. & $\begin{array}{ll}28.7 & \pm \\
3.34 & \end{array}$ & $28 \pm 2.67$ & $\begin{array}{ll}28.9 & \pm \\
1.24 & \end{array}$ & .983 & .018 & Insignificant \\
\hline & Wrist & $\mathrm{cm}$. & $\begin{array}{ll}17.4 & \pm \\
1.67 & \end{array}$ & $18.2 \pm 1.47$ & $\begin{array}{ll}18.5 & \pm \\
0.79 & \end{array}$ & .459 & .830 & Insignificant \\
\hline
\end{tabular}

Table (4)

Disparity analysis between the measurements of players' positions in the studied physiological variables $N(=15)$

\begin{tabular}{|c|c|c|c|c|c|c|c|}
\hline \multicolumn{2}{|c|}{$\begin{array}{c}\text { Play } \\
\text { positions/ } \\
\text { variable }\end{array}$} & $\begin{array}{c}\text { Position } \\
2\end{array}$ & $\begin{array}{c}\text { Position } \\
\mathbf{3}\end{array}$ & Position4 & Sign. & \multicolumn{2}{|c|}{ (D) Value } \\
\hline 8 & $\begin{array}{l}\text { coercive } \\
\text { Pulmonary } \\
\text { capacity }\end{array}$ & $\begin{array}{l}4.21 \\
0.33\end{array}$ & $\begin{array}{l}4.16 \quad \pm \\
7.43\end{array}$ & $\begin{array}{l}4.03 \\
0.36\end{array}$ & .741 & .307 & Insignificant \\
\hline . & $\begin{array}{l}\text { Coercive } \\
\text { expiratory } \\
\text { volume in } \\
\text { the } 1^{1 t} \text { sec. }\end{array}$ & $\begin{array}{l}3.31 \quad \pm \\
0.11\end{array}$ & $\begin{array}{l}3.38 \quad \pm \\
0.36\end{array}$ & $\begin{array}{l}3.21 \\
0.20\end{array}$ & .570 & .588 & Insignificant \\
\hline.$\frac{\pi}{00}$ & Percentage & $\begin{array}{r}82.45 \\
\pm 8.98 \\
\end{array}$ & $\begin{array}{r}81.57 \\
\pm 4.09 \\
\end{array}$ & $\begin{array}{r}80.24 \\
\pm 4.66 \\
\end{array}$ & .858 & .155 & Insignificant \\
\hline$\frac{\frac{0}{0}}{\frac{0}{0}}$ & $\begin{array}{l}\text { Maximum } \\
\text { voluntary } \\
\text { ventilation } \\
\text { pulmonary }\end{array}$ & $\begin{array}{l}114.9 \pm \\
9.38\end{array}$ & $\begin{array}{l}118.57 \\
\pm 12.66\end{array}$ & $\begin{array}{l}112.55 \pm \\
6.98\end{array}$ & .639 & .465 & Insignificant \\
\hline
\end{tabular}


Tables (2, 3, 4) show that there are no statistical morale significant differences at level (0.05) between the measurements of players' positions in the physical, physiological and some anthropometric measurements. While there are statistical morale significant differences at level (0.05) between the players' positions of the anthropometric measurement (sitting to deter, arms' width) and to clarify the differences among these measurements, the researcher calculated the least morale difference using (L. S. D.) test to determine the differences significance between these measurements as shown in table (5).

Table (5)

Differences' significance among the measurements averages of players' positions in the studied anthropometric measurements

\begin{tabular}{|c|c|c|c|c|c|c|}
\hline \multirow[b]{2}{*}{ variables } & \multirow[b]{2}{*}{ Positions } & \multirow[b]{2}{*}{ Mean } & \multicolumn{3}{|c|}{ Averages' differences } & \multirow{2}{*}{$\begin{array}{c}\text { L. S. } \\
\text { D. } \\
\text { value }\end{array}$} \\
\hline & & & $\begin{array}{c}\text { Position } \\
2\end{array}$ & $\begin{array}{c}\text { Position } \\
3\end{array}$ & \begin{tabular}{|c|} 
Position \\
4 \\
\end{tabular} & \\
\hline \multirow{3}{*}{$\begin{array}{l}\text { Sitting to } \\
\text { block }\end{array}$} & $\begin{array}{c}\text { Position } \\
2\end{array}$ & 150.60 & & 0.01 & 0.43 & \\
\hline & $\begin{array}{c}\text { Position } \\
3 \\
\end{array}$ & 155.60 & 0.01 & & 0.003 & \\
\hline & $\begin{array}{c}\text { Position } \\
4\end{array}$ & 149.20 & 0.43 & 0.003 & & \\
\hline \multirow{3}{*}{$\begin{array}{l}\text { Arms' } \\
\text { width }\end{array}$} & $\begin{array}{c}\text { Position } \\
2\end{array}$ & 192.80 & & 0.22 & 0.11 & \\
\hline & $\begin{array}{c}\text { Position } \\
3 \\
\end{array}$ & 189.20 & 0.22 & & 0.010 & \\
\hline & $\begin{array}{c}\text { Position } \\
4\end{array}$ & 192.80 & 0.11 & 0.010 & & \\
\hline
\end{tabular}

(D) Table value at level (0.05), and temperature degree $(7.2)=4.256$. Table (4) show that there significant differences at level are statistical morale (0.05) among the 
measurements of players' positions in the following anthropometric measurements:

- $\quad$ Sitting to block.

- Arms' width.

Discussion of Results:

Tables $(4,5)$ show that there are statistically significant differences at level (0.05) between the measurements of players' positions in the following anthropometric measurements (sitting to block, arms' width). Table (5) show that there are statistically significant differences in sitting to block measurement between position (2) and position (3) in favor of position (3), also between position (3) and position (4) in favor of position (3). There are no statistically significant differences between position (2) and position (4) in favor of position (2). The researcher attributes this to the following:

- The law of skill performance (8) in (sitting) volleyball for the disabled article (1:4:9) (in all the cases of play movements, the player must be touching the playground with any part of his anthropometric between the butt and the shoulders, and completely bans standing, or raising the anthropometric or making any steps) this shows the importance of the height from sitting while the arms are highly raised (sitting to block), the trunk height from sitting which resembles the total height of healthy people arms' width are distinguished and effective measurements in achieving the attack skills on the net (swift hitting, block wall) to increase the team's attack superiority to substitute the lack of jumping to overcome the block wall as happens in volleyball for healthy people. This agrees with Alsaied Abdel Maksoud (2007) (2) who indicated that the high levels are only achieved by the athletes that have special bases that suit the type of the practiced activity. As each activity requires special anthropometric characteristics that should be taken into consideration when selecting the athletes to practice this activity. 
Mohammed Sobhy Hassanin (1995) (4) indicate that the determinants of physical structure are the most stable all over the athletic life of the athlete. The coach no matter how skillful he is, will not able to make a hero out of an unqualified anthropometric; as training programs and intense practice result in the correct physical structure, superiority requirements and the athletic creativity in the specialized athletic activity. This seems reasonable considering that position (3) is the main specialization of block wall in the team. One of the most important advantages is height so that the player can block the wall in position (3) and also move to positions (2) or (4) as he is facing deception in the attack formation of the other team. Moreover, the height allows the player to achieve the maximum altitude over the net to cover the biggest possible space of the playground, which helps the team to take the suitable defense formation behind the block Also, there are no statistically morale significant differences at level (0.05) in the arms' width measurement between position (2) and position (3), and also between position (2) and position (4). Whereas, there are statistically morale significant differences at level (0.05) between position (4) and position (3) in favor of position (4). The researcher attributes this to:

- The nature of the technical performance of sitting volleyball of the physically disabled and the net height reaches $(1.15 \mathrm{~m})$ rule (2.2.1) (1), also the dual work of the arms imposes difficulty in the motor and technical performance. This showed the anthropometric measurement (arms' width) as an important one for players of both ends of the playground (2) (4) which allow them to defend in the side and front directions without the need to move; which imposes a dual work of the arms which in turn represents a special difficulty.

\section{Conclusions:}

In light of the nature of this study, sample, used method 
and results of the statistical analysis, and in the limit of this research, the researcher reached the following conclusions:

1- There are no statistically significant differences between play positions in (sitting) volleyball for the disabled in the studied physical variables.

2- $\quad$ There are no statistically significant differences between play positions in (sitting) volleyball for the disabled in the studied physiological variables.

3- There are statistically significant differences between play positions in (sitting) volleyball for the disabled in some of the studied anthropometric variables (sitting to block, arms' width).

\section{Recommendations:}

1- The anthropometric measurements (sitting while the arms are highly raised (to block), arms' width) are considered indicators for selection in sitting volleyball (for disabled).

2- To perform more experimental studies on the effect of sitting volleyball on the physical and physiological status of the Saudi players.

\section{References:}

1) Abdel Hakim Gawad Almatar and others (1996): "the reality of disabled sport in Saudi Arabia, Educational Researches center, issue 115, faculty of Education, King Saud university, Riyadh.

2) Alsaied

Abdel

Maksoud (1997): Training Theory, General Bases, Part 1, Dar Port Saied for publishing.

3) Antonio Ignacio Cuesta-Vargas a, Berta PazLourido b, Alejandro Rodriguez (2011): Physical fitness profile in adults with intellectual disabilities: Differences between levels of sport practice, Research in Developmental Disabilities 32 (2011) 788-794

4) Francesco Di Russo, Alessandro Bultrini, Stefano Brunelli, Anna Sofia Delussu, Lorenzo Polidori,4 Francesco Taddei,1 Marco Traballesi, 3,4 and Donatella Spinelli (2010): Benefits of Sports Participation for Executive Function in Disabled Athletes, 
Journal Of Neurotrauma 27:2309-2319 (December)

5) Helmy Ibrahim, Layla Farahat (1998): Physical Education and Recreation for the disabled, Dar Elfekr Elaraby.

\section{6) International}

\section{Paralympics}

committee (2012): official sitting volleyball rules 2009 - 2012 .

\section{7) Mahmoud Hamdy} Mohammed Ibrahim (2003): the contribution percentages of some special physical abilities in the skill performance level of excellent players in the sitting volleyball, the scientific magazine for sport and physical education, issue 24 , faculty of physical education for females, Alexandria university.

8) Mohammed Sobhy Hassanin (1995): the Anthropometric Patterns of sport Heroes of both genders, Dar Elfekr Elaraby, Cairo.

9) Nancy A. Murphy, Paul S. Carbone, and the Council on Children with Disabilities (2008): Promoting the Participation of Children with Disabilities in Sports,
Recreation and Physical Activities, 129 (4): e1103, American Academy of Pediatrics

10) Pamela E. Wilson, MD, Gerald H. Clayton (2010): Sports and Disability, the American Academy of Physical Medicine and Rehabilitation, Vol. 2, Iss. 3, Supplement 1 